\title{
How can speech-language therapists and audiologists enhance language and literacy outcomes in South Africa? (And why we urgently need to)
}

\author{
Harsha Kathard \\ Lebogang Ramma \\ Michelle Pascoe \\ Department of Health and Rehabilitation Sciences, University of Cape Town
}

Heila Jordaan

Sharon Moonsamy

Department of Speech Pathology and Audiology, University of the Witwatersrand

Anna-Marie Wium

Sandra du Plessis

Department of Speech-Language Pathology and Audiology, University of Limpopo (Medunsa campus)

\section{Lidia Pottas}

Department of Communication Pathology, University of Pretoria

Nasim Banu Khan

Department of Health, KwaZulu-Natal

Corresponding author: H Kathard (harsha.kathard@uct.ac.za)

\begin{abstract}
Basic education in South Africa faces a crisis as learners fail to achieve the necessary outcomes in the related areas of language and literacy. The aims of this paper are twofold. Firstly, we aim to describe and discuss the education crisis by outlining the educational landscape, relevant policy imperatives and implementation challenges in post-apartheid education. The systemic factors contributing to the literacy crisis are emphasised. Secondly, we argue that speech language therapists and audiologists (SLTAs) have a role to play in supporting basic education in South Africa through developing language and literacy. It is suggested that the professions of speech-language pathology and audiology must be socially responsive and population-focused in order to make meaningful contributions to development in South Africa. The potential roles of SLTAs are discussed with suggestions for further actions required by the professions to enable a contextually relevant practice in a resource-constrained environment.
\end{abstract}

Barbara Ehren (Department of Communication Sciences and Disorders, University of Central Florida) responds to the paper by raising the issues that SLTAs should be cognisant of, and making suggestions for the way forward.

Keywords: language, literacy, basic education, speech language therapist and audiologist roles, South Africa

'Creating literate environments and societies is essential for achieving goals of eradicating poverty, reducing child mortality, curbing population growth, achieving gender equality and ensuring sustainable development, peace and democracy.'

Koichiro Masuura (2005, p. 5)

'In today's era of globalisation, economic growth depends increasingly on an educated workforce that is poised to take advantage of opportunities.'

USAID (2004, p. 2)

Development as an ethos of practice for speechlanguage therapists and audiologists (SLTAs)

In post-apartheid South Africa, all sectors have an obligation to contribute to the building of a democratic nation. To sustain this democracy, education as a basic human right for all people is fundamental (UNESCO, 2005); not having essential literacy skills is morally indefensible and an appalling loss of untapped human potential and economic capacity. As language is the medium used in the classroom for teaching and learning, it has major implications for a collaborative role between teachers and SLTAs. The professions of speech-language pathology and audiology are key roleplayers in this process. In this paper, we consider how the professions of speechlanguage therapy and audiology can advance development in South Africa through their contributions to Basic Education.
The notion of development in this paper is underpinned by Sen's (2001) conceptualisation of development as expansion of freedoms allowing choice. Many countries in the world, including South Africa, face serious challenges such as oppression, poverty, illiteracy, hunger, disease and threats to civil liberties. According to Sen (2001), development is about how we overcome these difficulties. The way to achieve development is to expand freedoms, allowing people to make choices. As human beings we aspire to having the right to elect our governments (political freedom), make choices about how we earn and spend (economic freedom), have opportunities to be educated and maintain good health (social freedom), engage with each other in a trusting way and benefit from protective social security. The different types of freedoms are interlinked; freedoms of one kind promote other kinds of freedoms.

In South Africa, we achieved political freedom in 1994 but have a long way to go in achieving social freedoms, as health and education remain key areas of challenge. In the domain of Basic Education the professions can make key contributions through advancing education by supporting literacy development. Literacy has been defined as 'an individual's ability to read, write, speak and compute and solve problems at levels of proficiency necessary to function on the job and in society, to achieve one's goals, and to develop one's knowledge and potential' (ASHA, 2002, p. 168). Literacy development in South African Basic Education is in a serious crisis. In 2003, the Department of Education investigated 


\section{GLOSSARY OF TERMS}

Annual National Assessments (ANAs)

Basic Education

Community service

Curriculum and assessment policy (CAPS)

District level

Early childhood development (ECD)

Ex-model C school

Foundation phase

Full-service school

Further education and training (FET)

General education

Independent school

Intermediate grades

Language in Education Policy (LiEP)

Language of learning and teaching (LoLT)

Ordinary schools

Pan South African Language Board (PanSALB)

Provincial departments of education
Annual National Assessment (ANA) in literacy and numeracy is performed for grades 3,6 and 9 to continually measure the performance of individual learners and that of classes, schools, districts, provinces and the country as a whole. It provides information on individual learner performance, but also informs the Department how the sector as a whole is functioning. Going forward, ANA results will enable the Department of Education to measure the impact of specific programmes and interventions to improve literacy and numeracy (Motshekga, 2011).

'Basic Education' includes both primary and secondary education and is guaranteed to everyone without any discrimination or exclusion based notably on gender, ethnicity, nationality or origin, social, economic or physical condition, language, religion, political or other opinion, or belonging to a minority. Beyond preschool education, the duration of which can be fixed by the State, Basic Education consists of at least 9 years and progressively extends to 12 years (UNESCO, 2007).

In South Africa community service differs from that in other countries, where it is related to volunteerism. In an effort to redress previous inequalities in the South African Health System, the Department of Health launched the National Human Resource Plan in 2006. Newly qualified graduates (e.g. medical and allied health professions) are employed by the government for a period of 1 year to provide professional services to communities (ranging from urban to rural) where a need exists to make up for the shortfall in such skills (Department of Health, 2006).

The National Curriculum and Assessment Policy Statement is a single, comprehensive, and concise policy document, which will replace the current Subject and Learning Area Statements, Learning Programme Guidelines and Subject Assessment Guidelines for all the subjects listed in the National Curriculum Statement Grades $R$ - 12. It is important to note that the development of National Curriculum and Assessment Statements must not be seen as a new curriculum but only as a refined and repackaged National Curriculum Statement Grades R - 12 (Department of Education, 2008).

Each provincial Department of Education is known as the 'provincial level' of management. Each provincial level has several 'district offices' known as the 'district level' of governance. Each school district is a geographical unit as determined by the relevant provincial legislation, or prevailing provincial practice, and manages a number of schools within a specific geographical district. District-based support teams are a group of professionals whose responsibility it is to promote inclusive education through training, curriculum delivery, distribution of resources, identifying and addressing barriers to learning, leadership and general management (Department of Education, 1996a, 1996b).

Early childhood development (ECD) covers the education of a child from the period from birth to 9 years of age which is a critical time of change in his/her social, physical, cognitive, and emotional development (Department of Education, 2001a). In the South African context ECD refers to the policies and an approach where parents and caregivers participate actively in their child's programme (family-centred approach) (Republic of South Africa, 2005).

Model C schools existed in the period just prior to democracy in South Africa. This categorisation no longer exists and the schools are therefore referred to as former/ex-model C schools. These former model C schools were permitted to top up their funding with fees payable by the parents of the schools. Thus, former model C schools varied in relation to their fees, budgets, teacher-to-student ratios, and quality of facilities (Department of Education, 1996a).

The foundation phase includes grades $\mathrm{R}, 1,2$, and 3. It provides the learning that forms the grounding or basis for literacy, numeracy and life skills (Department of Education, 2002).

Full-service schools are ordinary schools which are specially equipped to address a full range of barriers to learning in an inclusive education setting (Department of Education, 2008).

Refers to levels of education which are above 'general education' but below 'Higher Education'. FET consists of grades $10-12$, which are offered in high schools (Department of Basic Education) or FET Colleges (previous technical colleges) (Republic of South Africa, 1998).

'General education' refers to the compulsory school attendance phase as referred to in section 3 of the South African Schools Act (Republic of South Africa, 1998).

Private or independent schools receive no funding from the government and are funded entirely by fees paid by the parents. The general perception is that the teacher: student ratio is lower than in government schools and that the standard of education is high (Department of Education, 1996b).

The intermediate grades of primary education comprise grades 4 - 6 (Department of Education, 2002).

The Language in Education Policy (LiEP) in South Africa provides for schools (depending on their needs) to adopt either one language as a medium for learning (home language) or use two languages: a home language in the early grades and a second one later as language of learning. According to the LiEP, whichever route is followed, the underlying principle is to maintain home language(s) while providing access to and the effective acquisition of additional language(s) (Department of Education, 1997).

The Revised National Curriculum Statement (RNCS) stipulates that the learner's home language should be used for learning and teaching wherever possible. This is particularly important in the foundation phase where children learn to read and write. The LoLT is the language of the majority of learners in the school/class, which is used for teaching in the classroom (Department of Education, 2002).

An ordinary school is a school that is not a special school (Department of Basic Education, 2011a).

PanSALB was established in 1995 to promote multilingualism in South Africa by fostering the development of all 11 official languages, while encouraging the use of the many other languages spoken in the country (PanSALB, 2011).

The provincial Departments of Education reside in each province of South Africa, under the National Department of Education. 


\section{GLOSSARY OF TERMS}

Public school

Revised National Curriculum Statement

School psychological services
Public schools are under the jurisdiction of the government and learners are subsidised by the provincial legislature. At public schools, parents vote on the level of school fees. Poor parents are given exemption or reductions. A public school may be either an ordinary public school or a public school for learners with special education needs. The latter should receive relevant educational support services for these learners (Department of Education, 1996b). Public schools are governed by elected school governing bodies, which have a significant say in the running of their schools.

The RNCS stipulates the specific outcomes and the assessment standards to be achieved for a specific grade. It provides the framework for what learners should know in order to become '... citizens that are multi-skilled, knowledgeable, sensitive to environmental issues and able to respond to the many challenges that confront South Africa in the 21st Century' (Department of Education, 2002).

The school psychological services were multidisciplinary units consisting of psychologists, remedial educationists, speech therapists/audiologists, and career counsellors. They provided services (assessment, management and intervention programmes) to learners who experienced barriers to learning, and in career counselling. Under the previous dispensation such services were available only to children in former white schools (Mashau, Steyn, van der Walt \& Wolhuter, 2008)

The senior phase of education comprises grades 7 - 9 with the child promoted to high/secondary school at the beginning of grade 8 (Department of Education, 2002).

South African Department of Education: Basic Education and Higher Education

The former Department of Education was the South African Government department responsible for education and training until 2009. Since then it has been split into the Department of Basic Education (schools) and the Department of Higher Education and Training (universities, technikons).

Special education

Special education in South Africa consists of special schools that offer segregated education for learners with specific education needs. A special school is one that is resourced to deliver education to learners requiring high-intensity support (Department of Basic Education, 2011a). Special education needs are based on specific disabilities: e.g. physical/mobility impairments, blindness, deafness, autism spectrum disorders, epilepsy, learning disability and cognitive impairments. literacy in grade 3 learners and found that $61 \%$ were not achieving grade level outcomes (Centre for Evaluation and Assessment, 2006). The poor performance of learners was also evident in the Progress in International Reading Literacy Study (PIRLS), which included South Africa in a comparison of literacy across 40 countries (Mullis, Martin, Kennedy \& Foy, 2007). Of significant concern was that South African grade 5 learners obtained the lowest scores despite being compared with grade 4 learners internationally (Scherman, van Staden, Venter \& Howie, 2008). It is even more distressing to learn that South African learners were reported to perform worse than those in neighbouring countries such as Mozambique, Swaziland and Botswana, even though a larger educational budget is allocated in South Africa (Barry, 2006). The situation has not improved over time. The recent report on the Annual National Assessment of 2011 (Department of Basic Education, 2011b) indicated that 6 million learners (grades 2 - 7) were assessed in language and mathematics as part of its quality improvement strategy. The findings revealed that only $12-31 \%$ of learners had reached an 'achieved level of performance'. The lowest results were evident in poor and rural communities. Learner failure is symptomatic of a systemic problem. Clearly, the quality of education is a problem and therefore all stakeholders are obliged to participate in improving schooling.

Given that literacy, as part of communication, is key to learning, the potential role of SLTAs is invaluable. In proposing development as an ethos of practice we advance an equity-driven approach that forces engagement with the challenges experienced by the majority of South Africans. In the past, the professions served a privileged minority and as we plan for the future the emphasis must be on how the population as a whole can benefit from SLTA services. The lens of the professions must expand from a traditional impairment-driven frame to a broader and more inclusive framework which considers not only those who have language and literacy learning impairments, but those who are at risk for literacy development and hence educational failure as a result of disabling systemic conditions.

In this paper, we share current thinking and relevant research regarding the contributions of SLTAs in promoting social freedom through our work in supporting literacy development. The emphasis is on our potential contribution to enhancing Basic Education since it is well established that a good foundation in education promotes long-term access to employment and health, but more fundamentally is a basic human right.

\section{Education in South Africa: the period prior to 1994}

The literacy crisis in South Africa cannot be understood without considering the history that shaped the current reality. The present education system with its systemic weaknesses was created by the combined influences of colonialism and racism. Three hundred years of colonialism resulted in a curriculum that denigrated and devalued local knowledge and identities, and reinforced the false notion that some people were superior to others. The curriculum was a vehicle to entrench the superiority of Europeans over native African inhabitants (Kumar, 2010). From 1961 to shortly before 1994, South Africa was under apartheid rule, a period characterised by an ideology of racial segregation and racial inequality (Cross \& Chrissholm, 1990, in Ratshitanga, 2007; Welch, 2003). The segregated education system provided a different quality of education to African, coloured, Indian and white learners. 'White education' ${ }^{1}$ benefited far more than that for other races in terms of fiscal allocation, which resulted in disparities in all aspects of education (Department of Education, 1995a). In stark contrast, the Bantu Education Act of 1953 was intended to provide an inferior education system for Africans ( $75 \%$ of the SA population) designed to maintain their status as labourers. Poor infrastructure, dilapidated and overcrowded classrooms, inadequate teacher training, lack of textbooks and learning materials characterised Bantu Education (Hartshorne, 1992). Apart from a racially segregated education system, there were two separate components for mainstream and special education, also characterised by racial disparity. This resulted in a fragmented education system with large numbers of learners being excluded from mainstream education (Naicker, 2000). The fragmented and inequitable education system adversely affected the professional training of teachers, especially in the Bantu Education system. Of significance is that the teachers trained for apartheid education continue to teach in post-apartheid education without effective support and training (Wium, Louw \& Eloff, 2010).

The democratic elections in 1994 aimed to open the doors of learning to all South Africans (African National Congress, 1995). South Africa emerged as a democracy with a new constitution, which in turn became the bridge between the apartheid past and political reform (Department

It is acknowledged that reference in terms of 'black education' and 'white education' is highly conteste in the current context. These terms are used to explain the racial divide that was created by the apartheid system. 
of Education, 1995b). The chapter on human rights in the Constitution of South Africa (1996) spelled out the values of equality, dignity and freedom. Simultaneously there was an international call to eliminate illiteracy throughout the world, and to facilitate scientific and technical knowledge and modern teaching methods (Charter of the United Nations, 1990).

\section{Educational aspirations and challenges post- apartheid}

With the birth of democracy and the progressive South African Constitution in 1994, a key priority has been the strengthening of Basic Education. In 2009, the schooling system in South Africa had over 12 million learners with approximately 400000 teachers in 25000 schools. As in other countries, the schooling system comprises public and independent sectors. More than 11 million learners were enrolled in 24699 public schools and were taught by 3872837 teachers in 2009 (Department of Basic Education, South African Country Report, 2011c), while 393447 learners attended 1207 independent schools, and were taught by 25230 teachers. These figures are based on learners attending 'ordinary' or mainstream schools, and do not include figures for learners attending 'special' schools.

The challenge set forth by the constitution was to create a just and equitable system that provides a good-quality education to all learners (Constitution of South Africa, 1996). Numerous reforms brought about fundamental changes in the process of redressing and enhancing equity: The South African Schools Act (Department of Education, 1996b) mandated children to attend school from the age of 5 to 15 . The National Education Policy Act (Department of Education, 1996c) and National Norms and Standards for School Funding (Department of Education, 1998) resulted in fundamental changes in schooling. Two types of schools are recognised - independent and public schools - with major resourcing inequities between them and within public schooling. Funding for schools is currently aimed at equity and redress. Therefore, schools are now categorised on the basis of their resources and revised funding norms are meant to advantage the poorest schools. A system of participative governance was implemented which devolved decision making, allowing school governing bodies to make decisions about many issues including fees and language policy. Hofmeyer (2000) argues that South Africa, as a middle-income developing country, demonstrates its commitment to education by spending $23 \%$ of its national budget and $7 \%$ of its gross domestic product (GDP) on education. However, even this investment has not been sufficient to address historical inequities and provide quality education.

One of the immediate consequences of the Schools Act was learner migration (Chisholm, 2008). Within the public schooling system there has been migration of African learners to Indian, coloured and white schools; while Indian and coloured learners migrated to white schools. The flow of learners from white, coloured and Indian schools to African schools is almost non-existent. As a consequence of learner migration, classrooms, especially in urban areas, have become racially and linguistically diverse with the schooling system being unprepared for such change. Nevertheless the majority of African learners, particularly those who cannot afford to enrol in fee-paying schools, remain in under-resourced schools benefiting little in education post-apartheid.

In addition to the changes discussed so far, the Inclusive Education Policy and the Language in Education Policy (LiEP) are of relevance to this paper. To raise education standards for all children, a more inclusive system was required. Such an inclusive approach is based on the classroom becoming a supportive environment for all members, including learners and teachers. Inclusive education is shaped by two major policy developments, namely White Paper 6 on Special Needs Education (Department of Education, 2001b) and the Revised National Curriculum Statement (RNCS) grades R - 9 (Department of Education, 2002). While the RNCS focuses on the curriculum and outcomes, Education White Paper 6 is focused on inclusion and creating learning environments which benefit all learners. Inclusion, viewed broadly, is intended to create opportunities for all learners - regardless of race, gender, language, culture, class and disability - to participate optimally in education. The policy emphasises a shift from learners' weaknesses to emphasising and building on their strengths. It also highlights the importance of collaborative learning and curriculum-based intervention. Learners with special needs, as well as those at risk, are in regular education or ordinary classrooms. To make it possible for all learners to access the curriculum, schools need to respond to learner diversity by transforming the curriculum and to minimise, remove, and prevent barriers to learning and development. The system, not only the learners, is required to change.

The RNCS is a curriculum guideline that describes the learning areas, learning outcomes and pace and sequence of learning expected in an academic year, as well as assessment standards (Department of Education, 2002). Although the Department of Education provided policy guidelines for each learning area, the onus rests on the nine provinces to customise these for their diverse populations. The RNCS specifically refers to the successful development of language and literacy as a basic foundation for successful learning in all phases for all learners throughout schooling. It emphasises the importance of quality of education during the foundation phase of schooling (grades R - 3), as well as the continued development of cognitive and linguistic skills through experiential learning. Although the policy emphasised the importance of language as a key part of learning during the school years, it is also well known that language learning is a lifelong process and one of the most reliable predictors of scholastic success is learners' language and literacy development prior to grade 1. The RNCS for the foundation phase outlines three learning areas: literacy (including listening and language), numeracy and life skills. Each of these main learning areas has specific learning outcomes and assessment standards linked to the concepts, skills and values to be taught at each grade level (Department of Education, 2002). The implementation of this curriculum relies on strong communication/language skills of teachers and learners. Unfortunately, the implementation and success of the revised curriculum has been negatively influenced by a variety of factors, e.g. resources and teacher preparedness. Among these, communication as a key factor has been overlooked and hence has become a barrier to learning.

When South Africa became a democracy in 1994, exemplary and progressive language policies were formulated to protect linguistic diversity (we have 11 official languages), promote language equity and develop the historically marginalised African languages. The LiEP (Department of Education, 1997) stipulates the right to education in the language of choice and promotes multilingualism within a framework of additive bilingualism, in which the home language (L1) is maintained while providing access to and the effective acquisition of additional languages (Bengu, 1997).

Despite these enlightened policies, there is agreement that they have not been implemented either in the broader public domain or in education. English continues to be the dominant language in South Africa (Balfour, 2010; Beukes, 2009; Jankie, 2009; Lafon, 2009; Singh, 2009; Sookrajh \& Joshua, 2009; Webb, Lafon \& Pare, 2010), at the expense and marginalisation of the other official languages (Alexander, 1997; Kamwangamalu, 2000; Mbatha and Pluddemann, 2004). Beukes (2009) attributes the incongruence between policy and practice to three main factors: the hegemonic position of English, the government's lack of political will, and negative attitudes to the African languages. However, there is a strong sense that African languages should be developed as instructional media, while access to English should not be denied (Alexander, 2010; Webb et al., 2010). A central question is how this should be accomplished, and decisions on language in education practices may need to be informed by the context of education. Table I reflects the language of learning across grades.

It is evident that in grades $1-3$ the majority of learners are schooled in African/home languages. Between 1998 and 2007 there has been an increase in the number of foundation-phase learners (grades 1 - 3) who learned in their L1. While the data indicate that there is a greater percentage of African L1 learners, it is also evident that approximately 


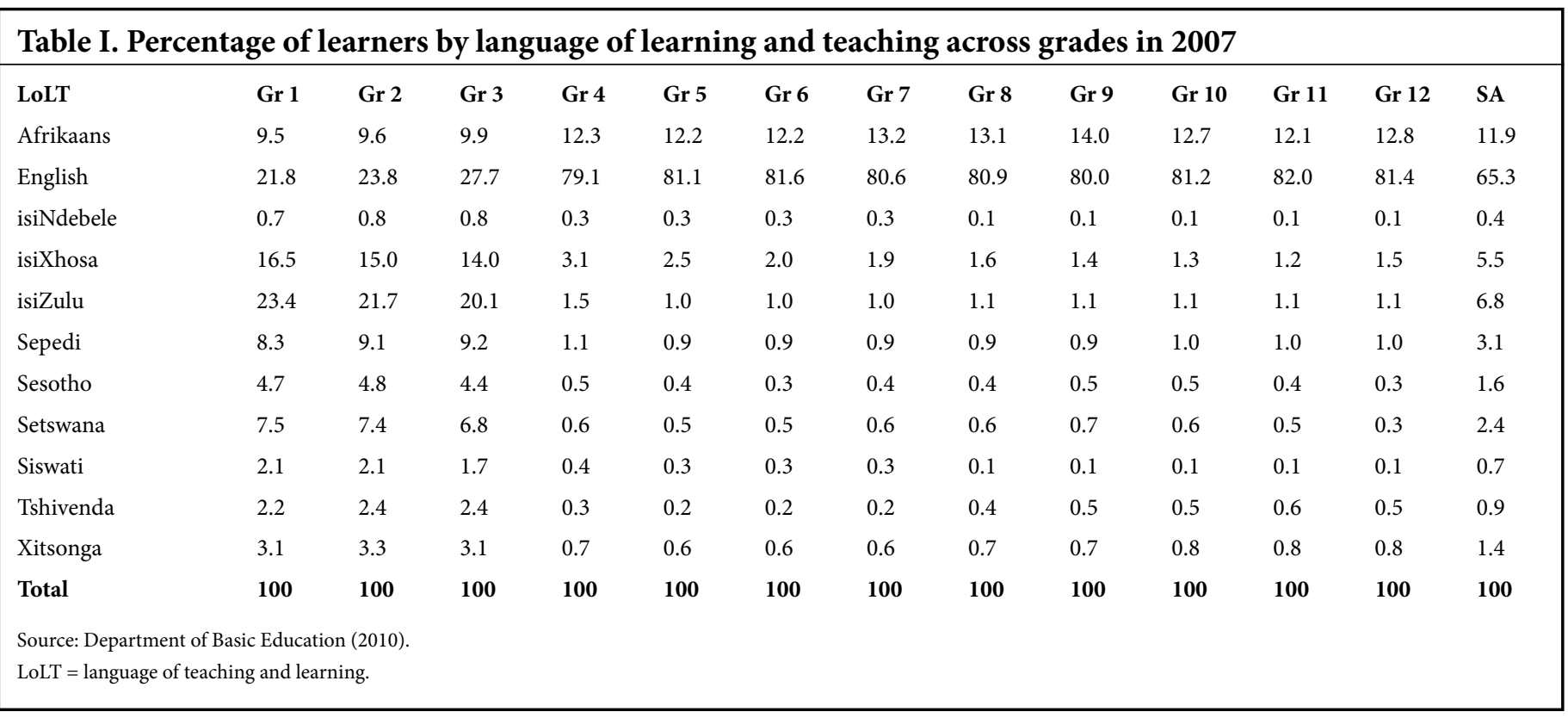

25\% have English and Afrikaans as LoLT. However, a major transition to English is evident at grade 4 as a consequence of the LiEP. In effect, the majority of learners do not learn in their L1 from grade 4. Of significance is that the majority of learners are not exposed to English or Afrikaans as a subject in grades $1-3$ but are expected to learn and be assessed in these languages from grade 4 onwards.

\section{Uneven performance}

Studies assessing the literacy and numeracy of primary school learners reflect significant inequality in achievement across different educational contexts, resulting in a bimodal frequency distribution, where the majority of learners perform in the lower range and a smaller number of children perform in the upper range (Fleisch, 2008; Taylor \& Yu, 2008). The learners who do well attend former model C schools (higher-fee-paying public schools) and independent schools (Fleisch, 2008). According to Webb et al. (2010, p. 276), two types of schools have evolved from the former model C system. The first type, referred to as 'upper ex-model C schools', are attended by elite and middle-class children of all races, who attain literacy and numeracy outcomes comparable to those of middle-class children anywhere else in the world (Fleisch, 2008). These schools are generally well resourced because the fees are determined by governing bodies. In these schools English or Afrikaans is typically used as the medium of instruction (LoLT) throughout, and the majority of teachers are first-language speakers of the LoLT.

The second type, referred to as 'lower ex-model C schools' (Webb et al., 2010, p. 276) have fewer facilities and resources because the fees are lower, and many parents reportedly do not pay fees at all. As a result of urbanisation and migration within the urban population (Chisholm, 2008), these schools are also demographically different from the upper ex-model C schools in that they are attended by predominantly African learners. White and Indian parents have either moved away from the area or have enrolled their children elsewhere (Chisholm, 2008; Webb et al., 2010). The teachers at these schools are predominantly English firstlanguage teachers but are also increasingly English second-language speakers. The medium of instruction at these schools is English from the first grade.

The use of English in these contexts is often determined by pragmatic reasons and is indicative of the heterogeneity in home language backgrounds of the learners in certain provinces. In this context, English as the LoLT may appear to be the only practical choice, since the complex multilingual composition of schools makes it difficult to select a particular African language as the LoLT. Rural and township schools, which are typically former African Department of Education and Training (DET) schools, are still attended predominantly by
African learners. These schools continue to have very little funding and are poorly resourced in terms of libraries, electricity, water, etc. Furthermore, teachers at these schools were trained by the Bantu Education system and therefore require significant reskilling to improve educational quality. As indicated previously, in these schools the official policy is to use the L1 as the LoLT up to grade 3 , frequently with little or no exposure to English as a subject in the foundation phase. From grade 4, learners then make the transition to English as the LoLT. However, this transition is not fully implemented in practice (Webb et al., 2010). It seems that in these schools, the L1 may be used (Brock-Utne \& Holmarsdottir, 2003), code switching is common, and urban vernaculars are increasingly used to facilitate understanding and classroom interaction, mainly because the English proficiency of learners and teachers is not adequate (Webb et al., 2010). Despite this, learners are officially assessed only in English and the fact that they have to demonstrate their knowledge and understanding in a language which is at best their second (L2) or even third language (L3) is simply not acceptable (Lafon, 2008; Webb, 2004; Webb et al., 2010). Furthermore, while they have not developed adequate English language competencies for school, they are also not advancing the development of the L1 for academic purposes resulting in underdeveloped linguistic competencies across languages. Poor/underdeveloped linguistic competence in LoLT is considered to be a contributing factor to poor performance of children in this context (Alexander, 2005; Brock-Utne \& Skattum, 2009; Heugh, 2009).

\section{Unsupported language transitions}

The transitional system was also implemented during the apartheid era, and was largely discredited in the Threshold project by Macdonald (1990), who showed that learners had not acquired a sufficient vocabulary to use English as the LoLT after 4 years of learning English as an L2. This policy has also been severely criticised by Heugh (2002, 2009), who argues that L1 instruction should be implemented for at least 8 years. Drawing on educational outcomes research in Africa commissioned by the UNESCO Institute for Education and the Association for the Development of Education in Africa (ADEA) in 2004, Heugh (2006) maintains that if early L1 instruction is to be beneficial, it must continue at least to the end of grade 6 but preferably longer, because the academic language and literacy needed for the whole curriculum cannot be developed in the first 3 years. In line with an additive bilingual approach, she recommends that the L2 is developed through subject teaching so that it can become a complementary medium of instruction during the second half of secondary school. A sudden and unsupported switch from L1 to L2 as LoLT is not necessarily the best way to ensure high levels of proficiency in the L2. In addition, the literature on optimal age of L2 acquisition (e.g. Marinova-Todd, Marshall \& Snow, 2000) suggests that in these 
contexts English need not be taught from the first grade, but can be introduced later when academic proficiency in the L1 has been established and developed. Older children who have consolidated the L1 and have access to a number of additional cognitive resources, such as explicit learning strategies, learn L2s more rapidly than younger children (MacWhinney, 2005; Paradis, 2004; Ullman, 2001). In contrast, younger children develop languages gradually, and teachers need to be aware of how long it takes for children to become proficient in the additional language if it is to be used as a medium of instruction.

Heugh (2006) argues that although issues of poverty and ill health (e.g. HIV/AIDS) compound the language problem and result in the generally low educational outcomes throughout Africa, the inadequacy of earlyexit transitional programmes has also been demonstrated in developed countries such as the USA and Canada, which are not as affected by such problems (e.g. Thomas \& Collier, 2002 cited in Heugh, 2006). Heugh $(2002 ; 2006)$ and Ramani, Kekana, Modiba, and Joseph (2007) believe that African languages can be used as the LoLT beyond the third grade. This claim is based on research by Heugh and Mahlalela-Thusi (2002), showing that considerable work was done on the development of African languages before, during and even after Bantu education. Heugh (2002) therefore urges stakeholders to consult these resources in African language departments across the country.

On the use of L1 instruction beyond grade 3, Heugh (2009) adds a very important caveat. She maintains that research findings on first- to third-grade children often show no achievement differences between L1 children and children in either L2 instruction from grade 1, early exit from L1 instruction, or dual-medium instruction programmes. However, she points out that gaps in performance start to emerge late in the third year and reach significant levels by grade 6 , and the only learners who perform at similar levels to their monolingual peers are those who have had instruction in their L1 as well as the L2 throughout. The implication of this is that even if $\mathrm{L} 2$ learners perform similarly to monolingual peers in the first 3 grades, they will fall behind if they do not receive support in both their L1 and English. Her findings explain the reasons for the large-scale referral of grade $4-6$ intermediatephase learners by teachers for literacy intervention in the Western Cape (Kathard \& Pillay, 2006). The teachers in linguistically diverse classrooms in poor communities were concerned that the majority of learners who made the sudden unsupported transition to English were not meeting grade level outcomes for literacy. The teachers reported that learners had not developed foundation-phase language and literacy skills and they were not skilled to support these learners (Navsaria, 2010).

Heugh (2006) claims that the language problems of children learning in their L2 have the most significant impact on their achievement in mathematics, since they achieve on average $10 \%$ less for mathematics than for language. In addition, Heugh (2009) cites recent evidence from Ethiopia, a much poorer country than South Africa, where children are instructed in their L1 (e.g. Amharic) for 4, 6 or 8 years. Children with 8 years of L1 instruction have higher scores across the curriculum (in mathematics, science and biology) than children with 4 or 6 years of instruction in the L1.

One of the widely used arguments against bilingual instruction and therefore the use of the L1, concerns the perception that such programmes do not provide sufficient exposure to the L2, as instruction time between L1 and L2 is divided (Obondo, 2008). This is known as the 'time on task argument' (Genesee, Paradis \& Crago, 2004, p. 168). However, although exposure is necessary for acquisition it is not sufficient (Obondo, 2008). This has been repeatedly demonstrated in research showing either no significant differences in the L2 proficiency of children in L2 monolingual programmes and bilingual programmes or an advantage to those in bilingual programmes (Chisholm, 2001). There is therefore overwhelming evidence that an additive bilingual approach in which the L1 is used for as long as possible while the child acquires other languages is the best for African children (Obondo, 2008), and yet there is resistance to this across Africa.

\section{Importance of African languages in education}

'Being able to use the language(s) one has the best command of in any situation is an empowering factor and conversely, not being able to do so is necessarily disempowering. The self-esteem, self-confidence, potential creativity and spontaneity that come with being able to use the language(s) that have shaped one from early childhood ... is the foundation of all democratic policies and institutions. To be denied the use of this language is the very meaning of oppression.' Alexander (2005, p. 3), in no uncertain terms, places a high priority on the use of African languages in education from the learners' perspective. While he acknowledges the value of empowering learners with English, he argues against the hegemonic use of English, i.e. English is privileged over all other languages and results in loss or decline of indigenous languages.

The use of African languages is also considered to be important for economic development and sustainability (Kamwendo, 2009). The period 2005 - 2014 has been declared the United Nations Decade of Education for Sustainable Development. This refers to the use of current resources in ways that will ensure their continued availability for future generations. Education systems are the avenue through which individuals can be developed to create a sustainable future in terms of environmental resources, economic prosperity, and social justice (UNESCO, 2005). The use of former colonial languages (English, French and Portuguese) as media of instruction in African schools impacts negatively on educational achievement when these languages are not well known by the learners (Kamwendo, 2009). Dlodlo (1999) and Bunyi (1999) elaborate on this point by proposing that these languages, which contain words and concepts that bear little relationship to the learners' daily experiences, deprive them of the opportunity to apply what they are learning to what they already know, which is a fundamental philosophy of learning (Reagan, 2009).

Finally, the use of African languages as media of instruction in African schools can help to minimise the impact of noisy classrooms on speech understanding of most learners. Anderson (1999) reported that an average first-grader misses 1 in every 6 words when learning in a class with too much background noise. Further, learners who learn in classrooms with high background noise levels such as schools near the airport or railway tracks, often exhibit poorer reading skills than learners who learn in less noisy classrooms (Anderson, 1999). The negative effect of poor learning environment (i.e. classrooms with too much background noise) on speech understanding has been shown to be much greater in children who learn in an L2 in comparison with those who learn in their native language (Crandell, Smaldino \& Kreisman, 2004; Tabri, Chacra \& Pring, 2010). Therefore, in South African schools where there are often less than optimal learning environments (e.g. overcrowded classrooms, too much background noise, etc.), using a language other than the language in which most learners are competent will severely limit their access to the information being communicated in class.

\section{Reasons for limited implementation of LiEP}

The main reasons for the dominance of English in education are the stigma attached to African languages as a result of 'Bantu Education' during apartheid (Nyika, 2009; Webb et al., 2010) and the view that English provides access to social and economic advancement. African parents associate poor-quality Bantu Education with being educated in an African language. Heugh (2000) argues that in the drafting of the outcomes-based curriculum, there was always a covert agenda that all children would ultimately learn in English, evidenced by the fact that language issues were reduced to the language and literacy learning area, as if they were not connected to the other learning areas. Development of terminology and materials in all the official languages, and teacher training for multilingual education and the new curriculum, were therefore not discussed (Heugh, 2000). The LiEP was announced 4 months after Curriculum 2005 was finalised, and Heugh (2000) maintains that the centrality of language in education was disregarded at a critical point in South Africa's history.

Webb et al. (2010) suggest the following additional explanations for the limited support for and non-use of African languages in education. First, 
learners have been found to have underdeveloped literacy in their L1, and are also aware of this (Barkhuizen, 2001; Pretorius, 2008; Webb et al., 2010). According to Webb et al. (2010), there is a general tendency for African language learners and teachers to overestimate their proficiency in English, and underestimate their L1 proficiency. Second, the African languages have not been adequately developed and standardised, and although there has been work in this area by the National Languages Bodies under the Pan South African Language Board (PanSALB), the standardised varieties have not been widely accepted, are not familiar to L1 speakers and are not used in formal contexts such as classrooms. In the development of the standard varieties there has been insufficient attention to status, acquisition and planning, and they are not seen to have economic or social power (Webb et al., 2010).

The development of technical terms in African languages is also challenging in that there is considerable difficulty in finding terms for concepts (Singh, 2009). For example, Southern Sotho has only one term, 'lebelo', for 'speed, velocity and acceleration' (Moji, 1998, p. 258), and in isiZulu there is only one word, 'amandla', for 'power, force and energy' (Wildsmith-Cromarty \& Gordon, 2009, p. 368). Dlodlo (1999, p. 321) attributes this conceptual void to the fact that African languages have not been used in education and consequently a modern scientific vocabulary has not developed. He argues for 'giving scientific meaning to generally accessible words that are explanatory of the context, rather than borrowing from European languages .... This approach implies that acquisition planning (the actual use of languages) drives corpus planning (the development of terminology by language bodies) so that teachers do not need to wait for terms to be developed before they can be used in the classroom (Wildsmith-Cromarty \& Gordon, 2009). Translation of English terminology is problematic in that English and the African languages are non-cognate languages, and there may be a lack of semantic and structural equivalence (Catford, 1965; Nida, 1975), lexical gaps (Fawcett, 1997) and translation shifts (Catford, 1965).

The third reason for not using African languages in education is the increasing use of urban, code-mixed vernaculars such as Tsotsitaal, Iscamtho and Pretoria Sotho, in Gauteng schools in particular (Cook, 2008; Lafon, 2005). Webb et al. (2010) attribute this practice to the absence of well-developed standard languages, and the rejection of standard varieties particularly by the urban youth. This is because new terms, developed by experts on language boards, are experienced as contrived (Wildsmith-Cromarty \& Gordon, 2009) and more aligned to rural dialects, which are slower to change than urban dialects, as a result of less contact with and influence from other languages (Anthonissen \& Gough, 1998). An example of this dichotomy is the tension between urban and rural isiZulu. The rural variety is considered to be the standard, but is virtually a foreign language to urban schoolchildren who do not learn successfully using this form (Webb et al., 2010).

While the post-apartheid schooling policies offer an ideology of improved education, implementation has been of serious concern. The key issues of language and learning have not been given sufficient consideration and, as a consequence, the majority of learners are being systemically disadvantaged and hence cannot meet grade level outcomes. Although school governing bodies (SGBs) have authority to make LoLT policy decisions, Pluddemann, Mati and Mahlalela-Thusi (2000) anticipated that in the absence of a comprehensive plan to educate and support SGBs on the language learning policies, it is likely that they will take the path of least resistance and adopt policies which are easier to implement. In effect, the evidence in Table I confirms their concern, i.e. there has been little innovation or development of multilingualism in schools as English remains the LoLT beyond grade 4. Furthermore, those who have specific language learning and other communication disabilities remain masked in the system as the majority of learners are at risk for not meeting educational outcomes. Clearly, the discussion so far has demonstrated the impact of a systemic problem on learner outcomes. While some learners might have specific impairments, the majority of learners are disadvantaged because of systemic problems at school and in their communities. The pressing question that needs to be addressed, therefore, is: How can SLTAs support the education system to enhance language and literacy?

\section{Speech language therapists and audiologists in} education: where are they?

In the current system, SLTAs do not play a visible role in the public sector education for a variety of reasons. Firstly, as a consequence of apartheidera policy, SLTAs were employed by the provincial Departments of Education at district level under the auspices of the 'School Psychological Services', benefiting a privileged minority. They also worked within a 'special school' model which offered services to learners based on their impairment/condition, e.g. schools for intellectually impaired/hearingimpaired/physically impaired children. In these historical educational contexts their traditional role was to identify learners who presented with 'speech and hearing deficiencies' and to provide the relevant therapy to treat them. Their interventions were guided by a medical model/ deficit model which resulted in a pull-out approach where the child rather than the system was the focus of intervention. As a consequence, a small number of learners received individual support which was not cost-effective. With the dawn of the new democracy, several of the SLTAs previously employed in the education system remained as district facilitators for learning without rendering direct professional services. While their roles are emerging, their impact has yet to be felt by the majority of learners and teachers in the public sector in ordinary/ mainstream classes who receive minimal direct support.

Secondly, therapy to school-age populations has been offered mainly by private practitioners who are parent-employed and work in a pullout model benefiting mainly individual learners who can afford help. Thirdly, although SLTAs are part of the education system, their roles in supporting general education in public sector schools are only emerging. They have not had opportunity to articulate their roles or the types of interventions which could potentially benefit education. Therapists are therefore still faced with the challenge, articulated by Lewis (2004), of making visible the links between language, literacy and learning, and demonstrating their role in supporting general education. A conceptual separation still exists between what is considered the domain of the teacher and the domain of the therapist. In moving forward, therapists must align interventions to engage with curriculum support and assist teachers and learners to meet learning outcomes.

The current human resource capacity of SLTAs is severely limited. The authors were unable to gain official documentary information on the number of SLTAs employed in the Basic Education sector and their role. However, available human resource data indicated that there are 186 speech-language therapists (SLTs) across the country appointed at 'special' schools. In addition, there are 73 'office-based' therapists (general category which includes occupational therapists and physiotherapists) whose job functions are unknown (Schoeman, personal communication, July 2011). Given school populations and current challenges in the education system, it is clear that SLTAs are grossly under-represented. Within a resource-constrained environment, SLTAs must therefore creatively craft service delivery models and types of interventions that would serve population needs. Furthermore, SLTAs must be able to demonstrate that their interventions are beneficial, particularly in parts of the system that experience disadvantage.

In the discussion that follows, the links between language, literacy and learning are explained and the potential role of SLTAs is discussed. While the evidence base for SLTA intervention in South Africa is minimal, developments in the USA and UK offer possibilities. The paper concludes with suggestions for further actions.

\section{Language, literacy and learning}

Language as a key part of communication is central to learning (Bohlmann \& Pretorius, 2002; Owens, 2002), as it is required for the development of reading and writing, and therefore becomes a prerequisite for all other learning areas. Linked to learning, language is not only an 
important part of a person's identity but also contributes to the understanding of other cultures and world views. It stimulates imagination and creativity, which link with arts and culture. It is also used to communicate information and to promote science, technology and environmental education. Language develops the critical tools required to become responsible citizens. The language learning area is crucial as it is central to people's lives (Department of Education, 2002). Language is used as the medium for learning in all learning areas, and underdeveloped language skills impact negatively on academic performance (Bohlmann \& Pretorius, 2002).

While spoken, and not written, language is the domain most often associated with SLTAs, a large body of research (Bishop \& Snowling, 2004; Stackhouse \& Wells, 1997) suggests that spoken and written language should be viewed on a continuum, with written language being developed on a foundation of spoken language, and phonological awareness acting as the mediating bridge between the two domains. Thus, SLTAs working in classrooms may be focused on any or all of a combination of these areas.

There are others who suggest that written and spoken language develop simultaneously and influence each other (Scott, 2005). Supportive of a simultaneous development stance, the Department of Education (2002) in South Africa recognises that language learning outcomes for the foundation phase are collectively those of listening, speaking, reading and viewing, writing, thinking and reasoning, and language structure and use (Department of Education, 2002). They maintain that these outcomes should be integrated when taught and assessed, even though they are presented as separate outcomes.

\section{SLTAs in other contexts}

While South African SLTAs work towards the development of contextually relevant intervention practices, they can draw on the experiences of SLTAs in other contexts around the world. American therapists in particular have shifted from a traditional pull-out model to a classroomfocused approach. Here the SLTA's role in the classroom is to support the development of a robust oral and written linguistic base, which includes a learner's L1 and any additional languages (Ehren \& Ehren, 2001).

Ehren (2009) describes the role of SLTs in a 'content literacy continuum', a five-level framework that addresses the speaking, listening, reading and writing needs of learners. Level 5 (therapeutic intervention) is the most intensive level where learners with language difficulties receive therapy from an SLT, either within the classroom setting or outside it. This is perhaps the model of working that many SLTs will be most familiar with. However, SLTs should also be involved at the other four levels, with Levels 1 and 2 involving close collaboration with classroom teachers, e.g. guiding the teacher's use of language, identifying learners in need of further interventions, and determining the language underpinnings of the curriculum. For Levels 3 and 4, the more intensive and specific role of the SLT, again in collaboration with teachers, is outlined. The Royal College of Speech Language Therapists (RCSLT, 2011) describes a similar system of working which emphasises the SLT's role at various levels within the school setting, ranging from highly specialised work with individual children to preventive work with all children or particularly vulnerable groups of children. The preventive focus should include working with parents and other community support structures to facilitate literacy development in the home context (Navsaria, 2010).

Because of the central role of language in learning (Slabbert, de Kock \& Hanttingh, 2009), a system responsive to the needs of all learners must first and foremost consider how language and communication for learning can be maximised. Given the link between audition, language and literacy, SLTAs should provide supportive structures, which promote and enhance spoken and written language (Owens, 2010). Learners and teachers need language support that is functionally related to the academic and social tasks of school. The classroom's cognitive activities are the best context, presenting the most significant and interactive opportunities for the learners, to enhance learning (Ehren,
2000). Having a close understanding of the relationship between curricular demands and the role that language and communication play in learning, teachers and SLTAs can address the academic and social challenges as a team within the classroom (Ritzman, Sanger \& Coufal, 2006). The role of the SLTA is to use classroom activities as the basis for intervention and implement a format of team-teaching where both the teacher and the SLTA teach small groups simultaneously, or where the teacher works with the larger class, and the SLTA works with a smaller group needing support. One-on-one classroom-based intervention that centres on language strategies for classroom use with selected students is not excluded. The SLTA also acts as a consultant who advises teachers and primary caregivers on intervention strategies, and sets joint goals and objectives with the classroom teacher. This model requires inservice training of all teachers as well as primary caregivers with regard to the language curriculum, including metalinguistic and metacognitive processes, syntax and morphology, and listening and literacy skills.

SLTAs can work with teachers to identify and ameliorate acoustic barriers in the classroom to promote accessibility of the teacher's speech to the learners. Further, they are better placed to advise teachers on the implications of hearing difficulties for individual learners, as well as devise effective management of their listening needs within a range of settings (British Association of Education Audiologists (BAEA), 2003). For these reasons SLTAs' contributions would be valuable when collaborating with teachers, in planning relevant and meaningful learning programmes for all learners. A developmental approach within the policy of inclusion and collaboration is essential in preventing later scholastic difficulties (Owens, 2010). Finally, because of their scopes of practice, SLTAs are also essential in serving as the 'key link' professionals between the education and health systems to ensure seamless service provision to learners and teachers. In South Africa, the current policy in its intention provides a firm grounding for developing a collaborative approach. In the Education White Paper 6, support is described as the provision of training, mentoring, monitoring, consultation and collaboration. Clearly, all stakeholders must work towards the practical implementation.

\section{SLTAs in classrooms: can we make a difference?}

Evidence from the international literature demonstrates that learners and teachers who have received support from SLT services have experienced positive outcomes supporting the goals of successful schooling (Ehren \& Ehren, 2001; McCartney, Ellis \& Boyle, 2009; Wilson, Nash \& Earl, 2010; Wren, Roulstone, Parkhouse \& Hall, 2001). A systematic review (Cirrin et al., 2010) of the evidence base regarding SLT intervention for primary school learners over the past 30 years suggests that: SLT intervention has positive outcomes; direct classroom-based intervention is at least as effective as traditional pullout models; and trained assistants can be as effective as SLTs when working with this population, but there are very few studies and an expanded research agenda is urgently required. This latter observation is particularly pertinent in our context.

There are few South African studies that demonstrate the effectiveness of SLTA involvement in mainstream schools. Moodley, Chetty and Pahl (2005) argue that SLTAs are well positioned to support language, literacy and learning given their skills base. Therefore they must craft their roles in relation to the RNCS and inclusion. They focused on the role of SLTAs in developing learning and teaching support material relevant for a multicultural population through use of folktales. They make a strong case for the collaboration between teachers and therapists, suggesting that success will depend on a conscious change of attitude regarding their roles and responsibilities.

Wium et al. (2010) reported on the benefits of teacher support in facilitating literacy and numeracy with foundation-phase learners in previously disadvantaged schools. They found that teachers benefited from a support programme provided by SLTAs, as they were better prepared to implement those learning outcomes for literacy and numeracy. Another local study by Du Plessis (1998) investigated whether a model of teamwork could lead to improved goal-setting and intervention at preschools where learners and teachers required 
support with language development. The results indicated that the most adequate goals and successful language intervention were achieved in the transdisciplinary model of team functioning between SLTAs and preschool teachers. It is speculated that role transfer, a specific characteristic of this model, led to the improvement. The sharing of knowledge, expertise and skills by professionals involved in education is notably the best way in which a learner's potential can be realised (Du Plessis, Hugo \& Soer, 2000). A further investigation was done into the support needs of preschool teachers regarding language acquisition by preschool learners acquiring the LoLT. Preschool teachers acknowledged the need for knowledge regarding language acquisition and the need for support. They were willing to consult and collaborate with other professionals, including SLTs in support of preschool learners (Du Plessis, 2005).

While these studies are encouraging, it is vital that SLTAs develop a strategy to enhance their presence in the education system.

\section{Opportunities, issues and actions \\ Becoming partners: Action Plan to 2014}

This paper has explained the current crisis in education, and its links to language and literacy development. Given the large-scale challenge facing South African education, it is imperative that SLTAs seek opportunities to support the national imperative for quality education. The Department of Basic Education, in recognising the enormity of the challenge, has formulated a longer-term vision reflected in 'Schooling 2025'. The immediate steps are documented in a 5-year plan, 'Action Plan to 2014' (Department of Basic Education; Notice 752 of 2010), which outlines 27 goals to improve the quality of education. SLTA input is particularly relevant to several goals, the first of which is to increase the number of learners in grade 3 who by the end of the year have mastered the minimum language and numeracy competencies for that grade. The second goal highlights the importance of sustaining literacy and numeracy competencies to grade 6 learners. SLTAs would have to consider how they could support the realisation of these goals in partnerships to support current strategies. For example, the ministry has initiated the workbook project in all 11 official languages. The aim of the workbooks is to support more effective teaching, which is recognised as a significant constraint. The workbooks are intended to assist teachers with teaching content knowledge, as well as to monitor how learners do tasks. SLTAs could assist with developing materials to ensure that both language and content goals are met. Furthermore, therapists could make an important contribution to the review of the RNCS, and specifically to the national Curriculum and Assessment Policy Statements (CAPS) which have been developed for each subject for all grades.

The provision of quality early childhood development has also been prioritised. The Department of Basic Education has indicated that all learners would have access to grade $\mathrm{R}$ by 2014 . SLTAs could make critical inputs into this process to ensure that language development and emergent literacy skills are prioritised in the curriculum and teacher training. The Teacher Development Programme has been launched through the participation of all stakeholders, creating a further opportunity for collaboration between teachers and therapists. Therapists could support pre-service and in-service teachers in a range of areas to improve literacy outcomes.

Clearly, SLTAs must intervene politically and raise awareness of their roles and their potential contribution. This process has been initiated by the Education Task Team in October 2010 under the auspices of the South African Speech-language Hearing Association. The task team have made submissions to the national Department of Education on the potential contribution of SLTAs, summarised below. While this is a first step, it is imperative that further strategic action is taken to ensure that the professions participate meaningfully in supporting Basic Education.

\section{Expand employment of SLTAs in Basic Education}

The further employment of SLTAs in the Department of Basic Education will provide systemic support in language and literacy development to support improved learning outcomes. In the current service delivery model, the Department of Health employs the majority of SLTAs who provide services for children under 6 years of age. School-aged learners are not given priority if they do not have an accompanying medical condition, leaving a major gap in support in the education sector. While the education sector has employed SLTAs, they service mainly schools catering for learners with special needs and are beginning to form part of district-based service delivery teams. However, the number of SLTAs is far from optimal and must be increased if teachers and learners are to obtain tangible support. The further employment of SLTAs will also affirm that the Department of Education is accepting responsibility for the support of learners and teachers, particularly in contexts where language and literacy problems are prevalent. The following employment options may be pursued:

- Community service posts. Each year, approximately 200 SLTAs graduate from university. Graduates could be integrated into the education system by using a strategy of compulsory community service in education. This strategy was put in place by the Department of Health in 2003, and has been successful in establishing services in under-resourced areas. In the future, the graduates could be placed in either health or education settings during their community service year as their roles straddle these sectors.

- Improving post provisioning in the Basic Education sector for qualified practitioners with emphasis on strengthening interventions to support language and literacy development in ordinary classrooms. At a minimum, SLTAs should be employed at every full-service school and collaborate on all district-based teams.

\section{SLTA competencies}

SLTAs will have to be (re)skilled to become effective participants in supporting Basic Education. While universities are aware of how SLTAs should be working to support Basic Education, the professions do not have guidelines for the specific competencies required to address the crisis. The majority of SLTAs trained in South Africa would require reskilling to develop competencies to address national priorities. Key issues that SLTAs must consider include the following:

- What kind of service delivery models would be relevant for the South African context? What would intervention priorities be? What type of service delivery model would be effective and cost-effective?

- How would SLTAs support the development of all languages, especially African languages, particularly as the majority of clinicians are mainly English or Afrikaans first-language speakers?

- How can SLTAs respond to the numerous calls to assist with developing English as an additional language? Would SLTAs need additional ESL competencies?

- How can SLTAs lead or participate in social innovation needed to respond to this magnitude of crisis?

- What human resource base would be required, given the large-scale challenge?

\section{Conclusion}

This paper has outlined the challenging landscape of Basic Education in South Africa. Difficulties with the past and current system have impacted on learners and teachers to create a crisis situation. There are no easy solutions, but there are choices facing the professions of speechlanguage therapy and audiology, which if judiciously made, may lead to important and significant contributions to the Basic Education sector in this country. SLTAs must pursue a development agenda to be socially relevant. USAID $(2004$, p.2) suggests that the economic growth of a country depends on an educated workforce that is poised to take advantage of opportunities. There is a dual meaning here for SLTAs. We must strive to contribute to the development of that workforce through the enhancement of language, learning and literacy in Basic Education. 
Secondly, as professionals ourselves we constitute a small but highly educated workforce and if we wish to ensure the future relevance and value of our work in South Africa, we should take advantage of the great opportunities that currently await us in the education system. The professions must be strategic in their engagement with education. But we should also do what is right: educated and literate individuals have better long-term access to employment and health - they have freedom. What bigger contribution can speech-language therapists and audiologists make than this?

\section{Response}

The respondent, Barbara Ehren, offers commentary on the issues raised and makes further suggestions for the way forward. We asked her: 'As a speech-language pathologist, how would you respond to this contextual challenge?'

I appreciate the opportunity to respond to this paper not only as a speech language pathologist (SLP) but also as an educator with a longstanding interest in systems change. What the authors call for is a major shift in the roles and responsibilities of SLPs in South Africa, which will require changes in the way SLPs view themselves and their work scope, as well as how other educators view them and their contributions to student achievement in general and literacy specifically. These changes in perceptions must be accompanied by new or revised implementation mechanisms, including substantive alterations in processes and infrastructures within the education system at many levels.

I wholeheartedly support this call for more substantive contributions of SLPs to literacy. It is in keeping with my own work, along with that of many colleagues in language/literacy and school practice who share this vision. It is inspiring to encounter kindred spirits working toward this end in another part of the globe. It is encouraging that mutual goals may provide an opportunity to collaborate on enhancing the impact of SLPs around the world, striving to make a difference in the lives of all human beings.

At the outset, I would recommend a clarification with regard to the inclusion of audiologists in this mix. I would not want to minimise their contributions in supporting access to instruction by addressing acoustic considerations, especially in noisy environments, and in working with children and adolescents who are hearing-impaired to promote literacy acquisition. However, I do not see their potential contributions to the overall literacy agenda to be on a par with SLPs, because SLPs have many more roles to play in a wider variety of areas affecting literacy. I think that including both professions in a single package of 'SLTA' convolutes the issue and fails to send a clear message about what respective roles should be. Rather, I would define a suggested role set in education for each profession separately. Therefore, in the rest of my commentary, I shall address only SLPs.

\section{The rationale for the summons}

This call for SLPs to participate more broadly in language and literacy instruction is crucial to nations that recognise literacy as central to the development and maintenance of a democracy and that appreciate the corresponding urgency of addressing poor literacy rates. A literate citizenry is essential to promoting full participation in the way of life of a democratic society. Further, in our technologically advanced world, workforce readiness requires high levels of literacy, way beyond what previously has been considered 'basic' (Ehren \& Murza, 2010). Therefore, a cogent argument is that with a matter of such urgency it behoves all segments of a society to be engaged in the effort, and SLPs should be no different. However, additional weight should be given to the case for SLP involvement, because they bring to the literacy table unique contributions, given their knowledge of language.

In fact, the American Speech-Language-Hearing Association (ASHA) recently promulgated as official policy a position statement and professional issues statement on the roles and responsibilities of SLPs in schools that embrace many critical roles, including those highlighting literacy within the context of SLPs' unique contributions and within a broad range of responsibilities (ASHA, 2010, p. 1): 'SLPs provide a distinct set of roles based on their focused expertise in language. They offer assistance in addressing the linguistic and metalinguistic foundations of curriculum learning for students with disabilities, as well as other learners who are at risk for school failure, or those who struggle in school settings'. Other companion roles articulated in the ASHA documents are in the areas of collaboration and leadership. The former arena lends credence to SLPs forging partnerships with other educators in support of literacy and the latter points to the advocacy needed from SLPs to assume new and expanded roles.

In supporting SLPs' contributions to the national imperative for quality education, I would endorse framing the conversation in terms of 'backward design' (Wiggins \& McTighe, 2005) (which is basically what the authors have done); that is, to advocate that all stakeholders start with the end in mind in defining roles for SLPs (or anyone else, for that matter). In such a construct, the larger picture of the social and economic goals for South Africa provides the target for educational goals. Where South Africa wants to be as a nation then becomes the starting point for discussing roles of SLPs. Working backward from that point, the next question is 'What has to happen in education to create the kind of society South Africans want?' and from there, 'What do SLPs have to do within educational systems to contribute to this grand plan?' This is a different approach from looking first at SLPs' roles based on their professional preparation and expertise.

My own experience in working with SLPs in many different states within the USA is that this approach provides a convincing rationale for them to consider doing things differently. They see their potential contributions as serving a larger purpose, a key factor in motivating them to make the necessary changes. A titillating challenge for SLPs is to expand their sphere of influence in areas of major consequence to their country so that role definition is no longer just a matter of 'This is what we do as SLPs' but 'This is what South Africa needs for us to do.' Of course, in the final analysis, professional preparation and expertise are considered in defining roles, but they are not the starting point.

\section{Implementation considerations}

Even if taking larger roles with literacy makes sense to SLPs and other stakeholders, the practical aspects of implementation is where the 'rubber hits the road'. For one thing, with the pull-out model having been the mainstay of service delivery, SLPs will need to expand their repertoire to accommodate refocused priorities. First, it is important to note that including more students and activities within the work scope of SLPs should in no way imply abandonment of students with communication disorders. Even with that population, SLPs would do well to consider alternatives to pull-out. For more effective and efficient services, a variety of delivery models, including in-classroom direct services and indirect services to teachers and caregivers (Ehren, 2000), should be considered. For example, when students with speech and language disorders are at a generalisation stage of therapy, pulling them out may not well serve the goal of transferring new behaviours to the classroom.

However, within a broader scope of concern for literacy status with more students, it is of even greater import to consider a variety of options. Especially in light of limited resource capacity, contributions of SLPs may in many instances be to assist teachers, other professionals and caregivers who might be the primary deliverers of intervention. Therefore 'indirect services' are important to include in a menu of service delivery options. Thus, SLP' roles in intervention may expand beyond direct work with students who struggle with literacy.

In this regard, I think it is helpful to think in terms of four types of activities with which SLPs may be involved:

1. Triaging students

2. Looking at students individually

3. Deciphering patterns of strengths and challenges in learning with an eye on language underpinnings (foundations) that may be involved 
4. Helping to decide who needs what service from whom

5. Guiding language-sensitive assessment/instruction/intervention delivered by others, including accommodations for students with disabilities. (This may be accomplished by consultation/problemsolving, demonstration teaching and provision of professional development to others.)

6. Providing direct intervention to students on language underpinnings in collaboration with others.

7. Providing speech and language therapy to students with communication disorders.

Given a broad array of service delivery options, SLPs will still need to make judicious selection of students to serve, directly and indirectly, deciding how best to use their expertise; otherwise, they will become overwhelmed with too much to do. A key component in effective and efficient deployment of personnel is collaboration among professionals to parlay resources and avoid redundancy or conflicting directions. Ehren and Laster (2010) and Goetze, Laster \& Ehren (2010) have recommended a partnership among specialists who share an interest and expertise in language; in the USA that would include the SLP, reading specialists and teachers of English language learners. With whom might SLPs join forces in South Africa?

As SLPs jump into the mainstream of education, they should avoid becoming just another pair of hands to do the work in schools that needs to be accomplished. That is, the tasks they are assigned should make use of their unique skill set in language and offer added value to the education of children and adolescents. Intervention activities need to be relevant to social and academic goals with the following caution: SLPs should not become responsible directly for mastery of subjects such as maths, social studies and science; instead they should facilitate access to these curricula through work on foundational language elements. Thus, curriculum provides the context, not the content of intervention, unless the curriculum under consideration is language arts. This approach does not require SLPs to be as expert as teachers in curriculum. What they need is enough knowledge about curriculum to select specific content as the raw material to teach language underpinnings.

\section{Content foci}

It is important to discuss language not just as prerequisite to learning but also as corequisite. Figure 1 is a graphic used by Deshler and Ehren (2008) to convey the ongoing contribution of language to all aspects of learning; it is helpful to explain how language is both foundational to learning at all stages, not just the basic foundation that precedes academic learning.

Rather than thinking of language as developing linearly along a continuum, it might be more productive to think of it as reciprocal along all points on the continuum of learning, as the above figure would imply. Research has consistently demonstrated reciprocal relationships with listening, speaking, reading, and writing (e.g. Bradley \& Bryant, 1983; Catts \& Kamhi, 2005; Englert \& Thomas, 1987; Gillon \& Dodd, 1995; Hiebert, 1980; Kroll, 1981; Ruddell \& Ruddell, 1994), all of which share linguistic, cognitive, metalinguistic and metacognitive underpinnings (Ehren, 2006). Highlighting the reciprocity of language processes and framing literacy as including listening, speaking, reading and writing, in my experience, helps SLPs to understand the relationship between oral and written language. Also, I would suggest that a focus on literacy should include more than phonology as a 'mediating bridge' and include differences in oral and literate styles with complexities in syntax, semantics and discourse structures.

\section{Systems change}

Even if there should be a resounding affirmation of the logic of this summons from many sources, change occurs slowly. Carefully consider the mountain you have to climb; don't underestimate the time and energy required to reach the summit! Attending specifically to the requirements of educational reform and change will help manage and sustain the process. Consult notable authors like Elmore

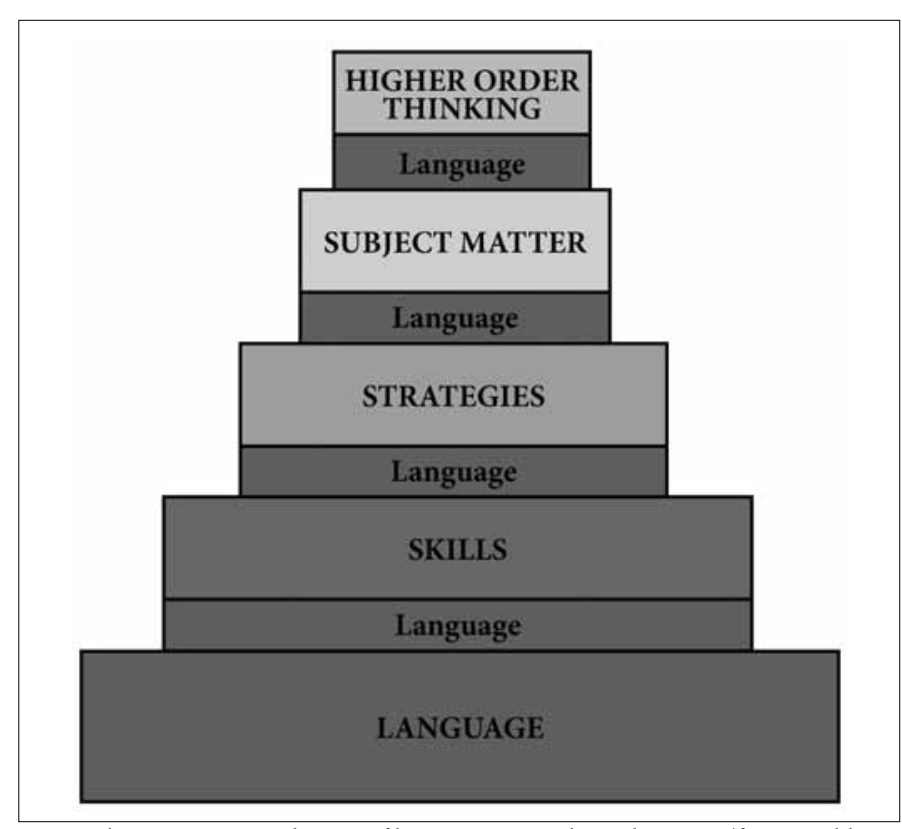

Fig. 1. The ongoing contribution of language to academic learning (from Deshler \& Ehren, 2008, used with permission).

(2004), Fullan (2005), Guskey (2005) and Hall \& Hord (2010), among others. Hall and Hord's concerns-based adoption model (2010) is one that will be of particular assistance in implementing and managing change.

The authors' observation that the traditional roles of SLPs are rooted in a deficit model implies that broader roles with literacy will require not only a different mind-set but also a different skill-set to serve in these capacities. To prompt and then sustain this change, both pre-service and in-service professional development will be needed. In the case of pre-service education, two issues are germane: $(i)$ preparing a sufficient number of SLPs to serve in expanded roles; and (ii) refining the university curriculum to include specific instruction in language and literacy issues, as well as methods in school practice and collaboration, among other important areas.

However, it is difficult to imagine that universities could address all aspects of implementing literacy-related roles in schools in sufficient depth. Therefore, an important companion piece is in-service education. This preparation will also be needed to retool practising SLPs. In this regard, the evidence base on high-quality professional development should be heeded in the development of SLPs' willingness and competency to engage in these roles (Desimone, Porter, Garet, Suk Yoon \& Birman, 2002; Penuel, Fishman, Yamaguchi \& Gallagher, 2007). Ongoing professional development, including experiences with initial learning, supported by follow-up activities will be essential. A major consideration is that if sufficient funding is not allocated to high-quality professional development for all involved, SLPs and their collaborators' efforts to move ahead will be in vain. (See standards for high-quality professional development from Learning Forward, formerly known as the National Staff Development Council at www. nsdc.org).

SLPs who embrace these roles conceptually should be prepared to encounter challenges along the way. For example, articulation of roles with literacy is a reiterative process. Just because SLPs explain to school district or school building administrators what they have to offer to address literacy needs, does not mean these administrators will internalise this message immediately, if their schema for SLP work is rooted in traditional roles.

Another consideration, however, is that to obtain buy-in from stakeholders, the latter must understand and appreciate what SLPs have to offer, starting with an appreciation for the role of language 
in all aspects of learning. I would not assume that most teachers have such understanding. One of the biggest obstacles we encounter in the USA is that teachers, especially of older students, do not understand the continued importance of language to the achievement of academic goals.

Another systems issue is measuring the impact of SLPs' contributions. This is easier said than done. The impact of SLPs on literacy will be difficult to measure, especially if we extend roles to more than direct service to students. As we advocate for a collaborative approach, the whole may not equal the sum of the parts; i.e. the benefit to students may not be additive when collaborators are involved. The interchange among professionals may create a synergy and produce results that reflect a 'shared creation', as Schrage (1995) describes. How can we tease out the contributions of individual professionals if we view the result of collaboration to be a shared creation and not merely a completion of delegated tasks by a 'team'? This is a matter of ongoing discussion in the USA.

\section{Conclusion}

In their closing section, the authors noted: 'if we wish to ensure the future relevance and value of our work in South Africa we should take advantage of the great opportunities that currently await us in the education system. I would suggest that relevance and value are the cornerstones that should mark the work of SLPs in all corners of the globe. I would further say that indeed the education system affords SLPs wonderful opportunities to use their knowledge and skills for substantive outcomes. We need to make a difference! Although that goal can be accomplished in a variety of ways, it makes sense that the impact of SLPs should be as broad as possible, given the needs of society and that literacy proficiency is surely one of those exigent needs. A mantra for me that may resonate with SLPs in South Africa is this quote from Hynds (1994, p. 162):

'I teach so that the world will be a better place. It's really that simple. I teach in the hope that some day, there might be a few more people who can use the gift of language in authentic ways: to respond to others, to learn new things, and ultimately, to positively influence the world in which we all must live.'

Dr Barbara J Ehren, CCC-SLP, ASHA Fellow

Board Recognised Specialist in Child Language

Professor

Director of the Doctoral Program

Interim Associate Chair

Department of Communication Sciences and Disorders

University of Central Florida

Orlando, Florida, USA

\section{References}

African National Congress (1995). A policy framework for education, training and development. Johannesburg. ANC.

Alexander, N. (1997). Language policy and planning in the new South Africa. African Sociological Review $1(1), 82-92$.

Alexander, N. (Ed.). (2005). Mother tongue-based bilingual education in South Africa: The dynamics of implementation. Cape Town: Salty Print.

Alexander, N. (2010). The potential role of translation as social practice for the intellectualisation of African languages. PRAESA Occasional Papers No. 33. Cape Town: PRAESA.

American Speech-Language-Hearing Association (ASHA) (2002). Designing and implementing an early literacy screening protocol: suggestions for the speech-language pathologist. Language, Speech and Hearing Services in Schools, 33, 84-101.

American Speech-Language-Hearing Association (ASHA) (2010). Roles and responsibilities of speechlanguage pathologists in schools [Professional Issues Statement]. www.asha.org/policy.

Anderson, K. (1999). When it comes to classroom acoustics, what's appropriate? Volta Voices, 6, 16-17.

Anthonissen, C., \& Gough, D. (1998). A pragmatic or purist approach to language standards: Implications for outcomes based education. Per Linguam, 14(1), 39-53.

Balfour, R. (2010). 'The long walk ...' Language Learning Journal, 38(3), 249-251.

Bantu Education Act No. 47 (1953). Retrieved on 8 January 2011 from http://www.disa.ukzn.ac.za/.

Barkhuizen, G. (2001). Learners' perceptions of the teaching and learning of Xhosa first language in Eastern and Western Cape high schools. Summary report. PanSALB Occasional Papers (3). Pretoria: Pan South African Language Board.

Barry, D. (2006). A partnership to improve literacy. JET Education Services Bulletin, 14, 1-3.

Bengu, S. (1997). Statement by Prof SME Bengu, Minister of Education on the New Language Policy in General and Further Education. In D. Brown (Ed.), Educational policy and the choice of language in linguistically complex South African schools. Durban: Education Policy Unit (Natal).

Beukes, A. (2009). Language policy incongruity and African languages in postapartheid South Africa. Language Matters, 40 (1), 35-55.

Bishop, D., \& Snowling, M. (2004). Developmental dyslexia and specific language impairment: Same or different? Psychological Bulletin, 130(6), 858-886.

Bohlmann, C., \& Pretorius, E.J. (2002). Reading skills and mathematics. South African Journal of Higher Education, 16(3), 196-206.

Bradley, L., \& Bryant, P. (1983). Categorizing sounds and learning to read: A causal connection. Nature $301,419-421$.

British Association of Education Audiologists (BAEA) (2003). Retrieved on 8 June 2011 from http://www educational-audiologists.org.uk/documents/roles.pdf.

Brock-Utne, B., \& Holmarsdottir, H.B. (2003). Language policies and practices in Africa - some preliminary results from a research project in Tanzania and South Africa. In B. Brock-Utne, Z. Desai \& M. Qorro (Eds.), The language of instruction in Tanzania and South Africa (pp. 80-102). Dar es Salaam: E \& D Publishers.

Brock-Utne, B., \& Skattum, I. (2009). Languages and education in Africa: A comparative and transdisciplinary analysis. Oxford: Symposium Books.

Bunyi, G. (1999). Rethinking the place of African indigenous languages in African education. International Journal of Educational Development, 19, 337-350.

Catford, J.C. (1965). Translation shifts. In L.Venuti (Ed.), The Translation Studies Reader (pp. 141-148). London: Routledge.

Catts, H., \& Kamhi, A. (Eds.). (2005). Language and reading disabilities (2nd ed.). Boston: Allyn \& Bacon.

Centre for Evaluation and Assessment (2006). PIRLS of wisdom: The what, where, when and how of the international reading literacy study in South Africa. Pretoria: Faculty of Education, University of Pretoria.

Charter of the United Nations (1990). Retrieved on 23 August 2010 from http://www.un.org/en/documents/ charter/index.shtml.

Chisholm, L. (2001). Values, multiculturalism and human rights in apartheid and post-apartheid South African curriculum. Paper delivered at the Saamtrek Conference, Cape Town, February.

Chisholm, L. (2008). Racial redress means different things for different schools: case studies of five Gauteng schools. HSRC Review, 6(2), 15-17.

Cirrin, F., Schooling, T., Nelson, N., Diehl, S., Flynn, P., Staskowski, M., Torrey, T, \& Adamczyk, D. (2010). Evidence-based systematic review: Effects of speech-language pathology service delivery model on communication outcomes for elementary school-age children. Language Speech and Hearing Services in Schools, 41, 233-264.

Constitution of South Africa (1996). Retrieved on 23 August 2010 from http://www.acts.co.za/constitution/ index.htm.

Cook, S. (2008). Language policies and the erasure of multilingualism in South Africa. In M. Lafon \& V. Webb (Eds.), The standardisation of African languages in South Africa: language political realities. Johannesburg: Insitut Francais d' Afrique du Sud.

Crandell, C., Smaldino, J., \& Kreisman, B. (2004). Classroom Acoustics: Measurement Procedures. Seminar in Hearing, 25(2), 189-200.

Department of Basic Education (2010). Notice 752 of 2010. Retrieved on 18 March 2011 from http:// edulibpretoria.files.wordpress.com/2008/01/action_plan_for_2014.pdf.

Department of Basic Education. (2011a). Report on the 2008-2009 annual surveys for ordinary schools. Pretoria: Basic Education.

Department of Basic Education (2011b). Report on Annual National Assessment of 2011. Retrieved on 8 August 2011 from http://www.education.gov.za/LinkClick.aspx?fileticket=1U5igeVjiqg\%3D\&tabid=3 588 mid $=1325$.

Department of Basic Education (2011c). South African Country Report: Progress on the implementation of the Regional Education and Training Plan (integrating the Second Decade of Education in Africa and Protoco on Education and Training). Retrieved on 8 August 2011 from http://www.education.gov.za/LinkClick. aspx? fileticket $=\mathrm{B} 3 \mathrm{Q} 11 \mathrm{NJKS3g} \% 3 \mathrm{D} \& \mathrm{tabid}=422 \& \mathrm{mid}=1261$

Department of Education (1995a). White Paper on Education and Training. Retrieved on 12 July 2010 from http://www.education.gov.za/LinkClick.aspx?fileticket $=855 \mathrm{f} T$ 9w3A2U\%3D\&tabid $=191 \& \mathrm{mid}=484$.

Department of Education (1995b). South African Qualifications Authority Act. Retrieved on 12 July 2010 from http://www.capegateway.gov.za/Text/2005/8/a58-95.pdf.

Department of Education (1996a). The organisation, governance and funding of schools (Education White Paper 2). Retrieved on 1 October 2011 from http://www.info.gov.za/whitepapers/1996/education2.htm.

Department of Education (1996b). The South African Schools Act, Act 84 of 1996. Retrieved on 12 July 2010 from http://www.info.gov.za/acts/1996/a84-96.pdf.

Department of Education (1996c). National Education Policy Act of 1996. Retrieved on 12 July 2010 from http://www.info.gov.za/acts/1996/a27-96.pdf.

Department of Education (1997). The language in education policy and national curriculum statement. Retrieved on 22 September 2009 from http://www.thuthong.doe.gov.za/getlanguages/languages/FAQ/ tabloid/2087.

Department of Education (1998). National norms and standards for school funding. Retrieved on 12 July 2010 from http://www.education.gov.za/LinkClick.aspx?fileticket=9DiDOH1U2k8\%3D\&tabid=1888 mid $=498$.

Department of Education (2001a). White paper 5 on early childhood education: meeting the challenge of early childhood development in South Africa. Retrieved on 13 January 2011 from http://www.polity.org.za/ govdocs/white_papers/educ6.html.

Department of Education (2001b). Education White Paper 6: Special needs education - Building an inclusive education and training system. Pretoria: Department of Education.

Department of Education (2002). Revised National Curriculum Statement grades $R$ - 9 (schools). Pretoria Department of Education.

Department of Education (2008). National strategy on screening, identification, assessment and support. Pretoria: Department of Education.

Department of Health (2006). A National Human Resources Plan for Health. Retrieved on 24 October 2011 from www.doh.gov.za/docs/factsheets/guidelines/hrplan/index.html.

Deshler, D., \& Ehren, B.J. (2008). CLC and RTI: Not a quantum leap. Florida SIM Update Conference, January Altamonte Springs, Florida.

Desimone, L.M., Porter, A.C., Garet, M.S., Suk Yoon, K., \& Birman, B.F. (2002). Effects of professiona development on teachers' instruction: Results from a three-year longitudinal study. Education Evaluation and Policy Analysis 24, 81-112.

Dlodlo, T.S. (1999). Science nomenclature in Africa: Physics in Nguni. Journal of Research in Science Teaching 36(3), 321-331.

Du Plessis, S. (1998). Spanfunksionering in 'n preprimere program vir kommunikasiegestremde leerder. Unpublished M Communication Pathology Dissertation. Pretoria: University of Pretoria. http://upetd. up.ac.za/thesis/available/etd-09292006-170657/

Du Plessis, S. (2005). Multilingual preschool learners: a collaborative approach to communication intervention. Unpublished DPhil Dissertation. Pretoria: University of Pretoria.

Du Plessis, S., Hugo, R., \& Soer, M. (2000). Spanfunksionering in 'n preprimêre program vir leerders met spesiale opvoedkundige behoeftes. Suid-Afrikaanse Tydskrif vir Opvoedkunde/SA Journal of Education

Ehren, B.J. (2000). Maintaining a therapeutic focus and sharing responsibility for student success: Keys to in-classroom speech-language services. Language, Speech and Hearing Services in Schools, 31, 219-229.

Ehren, B.J. (2006). Partnerships to support reading comprehension for students with language impairment. Topics in Language Disorders, 26(1), 42-54.

Ehren, B. (2009). Response to intervention: SLPs as linchpins in secondary schools. ASHA Leader, May 5 , $10-13$

Ehren, B.J., \& Ehren,T.C. (2001). New or expanded literacy roles for speech-language pathologists: Making it 
happen in the schools. Seminars in Speech and Language, 22(3): 233-241.

Ehren, B.J., \& Laster, B.J. (2010, April). The language of collaboration in RTI. International Reading Association Convention, Chicago.

Ehren, B.J., \& Murza, K.A. (2010). The urgent need to address workforce readiness in adolescent literacy intervention. Perspectives on Language Learning and Education, 17, 93-99.

Elmore, R.F. (2004). School reform from the inside out: Policy, practice, and performance. Cambridge, MA Harvard Education Press

Englert, C.S., \& Thomas, C.C. (1987). Sensitivity to text structure in reading and writing: A comparison between learning disabled and non-learning disabled students. Learning Disability Quarterly, 10, 93-105. Fawcett, P. (1997). Translation and language: Linguistic theories explained, Manchester: St Jerome Publishing

Fleisch, B. (2008). Primary education in crisis: why South African school children underachieve in reading and mathematics. Cape Town: Juta.

Fullan, M. (2005). Leadership \& sustainability: System thinkers in action. Thousand Oaks, CA: Corwin

Genesee, F., Paradis, J., \& Crago, M. (2004). Dual language development and disorders: a handbook on bilingualism and second language learning. Baltimore: Paul H. Brookes.

Gillon, G., \& Dodd, B. (1995). The effects of training phonological, semantic, and syntactic processing skills in spoken language on reading ability. Language, Speech, and Hearing Services in Schools, 26(1), 58-68.

Goetze, S., Laster, B., \& Ehren, B.J. (2010). RTI for secondary school literacy (pp. 173-211). In M. Lipson \& K. Wixon (Eds.), Successful approaches to RTI: Collaborative practices for improving K-12 literacy. Newark, DE: International Reading Association.

Guskey, T.R. (2005). Taking a second look: Strong evidence reflecting the benefit of professional development is more important than ever before. Journal of Staff Development, 26(1), 10-18.

Hall, G.E., \& Hord, S.M. (2011). Implementing change: Patterns, principles, and potholes (3rd ed.). Boston, MA: Pearson Education.

Hartshorne, K. B. (1992). Crisis and challenge: Black education 1910-1990. Cape Town: New York: Oxford University Press.

Heugh, K. (2000). The case against bilingual and multilingual education in South Africa. Cape Town: PRAESA Occasional Papers 6.

Heugh, K. (2002). The case against bilingual and multilingual education in South Africa: Laying bare the myths. Perspectives in Education, 20(1), 171-196

Heugh, K. (2006). An evaluation of language education models in Africa: findings \& recommendation from the UNESCO Institute for Education-ADEA stocktaking report on Lingua. Paper presented at the International Conference on Bilingual Education, Maputo, Mozambique.

Heugh, K. (2009). Into the cauldron: An interplay of indigenous and globalised knowledge with strong and weak notions of literacy and language education in Ethiopia and South Africa. Language Matters, 40(2), 166-189.

Heugh, K., \& Mahlalela-Thusi, B. (2002). Terminology and schoolbooks in Southern African languages: Aren't there any? PRAESA Occasional papers (10). Cape Town: PRAESA

Hiebert, E.H. (1980). The relationship of logical reasoning ability, oral language comprehension, and home experiences to preschool children's print awareness. Journal of Reading Behavior, 12, 313-324

Hofmeyer, J. (2000). The emerging school landscape in post-apartheid South Africa. Retrieved on 8 June 2010 from http://www.sun.ac.za/if/Taakgroepe/iptg/hofmeyr.pdf.

Hynds, S. (1994). Making connections: Language and learning in the classroom. Norwood, MA: ChristopherGordon

Jankie, D. (2009). Nurturing the dialogue on mother tongue education in Southern African societies. In G. Kamwendo, D. Jankie \& A. Chebanne (Eds.), Multilingualism in education and communities in Southern Africa. UB Tromso Collaborative Programme for San Research and Capacity Building.

Kroll, B. (1981). Developmental relationships between speaking and writing. In B. Roll \& R. Vann (Eds.) Exploring speaking-writing relationships: Connections and contrasts (pp. 32-54). Urbana, IL: Nationa Council of Teachers of English.

Kamwangamalu, N.K. (2000). Language policy and mother tongue education in South Africa. The case for a market oriented approach. Paper presented at the Georgetown University Roundtable on Languages and Linguistics (GURT), Georgetown University, Washington, DC, May.

Kamwendo, G. (2009). African languages, education and sustainable development: An introduction Language Matters, 40(1), 1-3.

Kathard, H., \& Pillay, M. (2006). Practice innovations: Language practitioners in (South African) classrooms. The International Journal of Learning, 13, 3-13.

Kumar, A. (2010). A synoptic view of curriculum studies in South Africa. Journal of American Association for the Advancement of Curriculum Studies, 6. Retrieved on 13 March 2011 from http://www2.uwstout.edu/ content/jaaacs/Kumar_V6\%20 copy.htm.

Lafon, M. (2005). The future of isiZulu lies in Gauteng: The importance of taking into account urban varieties for the promotion of African languages, with special reference to isiZulu. Issues for a debate. In V. Webb, A. Deumert \& B. Lepota (Eds.), The standardisation of African languages in South Africa. Pretoria: PanSALB

Lafon, M. (2008). Asikhulume! African languages for all. A powerful strategy for spearheading transformation and improvement of the South African education system. In M. Lafon \& V. Webb (Eds.), The standardisation of African languages in South Africa: language political realities (pp. 35-59). Johannesburg. Insitut Francais d' Afrique du Sud.

Lafon, M. (2009). Language policy and nation-building in post-apartheid South Africa. Language Matters, $40(2), 261-265$.

Lewis, F. (2004, winter). Speech therapists in schools: Curriculum integration and curriculum innovation challenges to the school speech-language therapist of today. Communiphon, 337, 36-37.

Macdonald, C.A. (1990). Crossing the threshold into standard three. Main report of the Threshold Project. Pretoria: Human Sciences Research Council.

MacWhinney, B. (2005). A unified model of language development. In J.F. Kroll \& A.M.B. de Groot (Eds.) Handbook of bilingualism: psycholinguistic approaches (pp. 49-67). Oxford: Oxford University Press.

Marinova-Todd, S.H., Marshall, D.B., \& Snow, C.E. (2000). Three misconceptions about age and L2 learning. TESOL Quarterly, 34(1), 9-34.

Mashau, S., Steyn, E., van der Walt, J., \& Wolhuter, C. (2008). Support services perceived necessary for learner relationships by Limpopo educators. South African Journal of Education, 28 (3).

Masuura, K. (2005). Foreword. In Education for all. Global Monitoring Report, Literacy for life. Paris UNESCO.

Mbatha, T., \& Pluddemann, P. (2004). The status of isiXhosa as an additional language in selected Cape Town schools. Cape Town: PRAESA, Occasional Papers 18

McCartney, E., Ellis, S., \& Boyle, J. (2009). The mainstream primary classroom as a language-learning environment for children with severe and persistent language impairment - implications of recent language intervention research. Journal of Research in Special Educational Needs, 9(2), 80-90.

Moji, N.C. (1998). Investigation of conceptual and language difficulties affecting the understanding of several mechanics concepts among some African teachers and students. $\mathrm{PhD}$ thesis, University of Natal, Pietermaritzburg.

Moodley, S., Chetty, S., \& Pahl, J. (2005). The school-based speech-language therapist: choosing multicultural texts. South African Journal of Communication Disorders, 52, 40-50.

Motshekga, A. (2011). Statement on the release of the annual national assessment results for 2011. Retrieved on 6 August 2011 from http://www.info.gov.za/speech/DynamicAction?pageid=461\&sid=19525\&tid= 36106.
Mullis, I., Martin, M., Kennedy, A., \& Foy, P. (2007). IEA's progress in International Reading Literacy Study in primary schools in 40 countries. Boston College: TIMSS \& PIRLS International Study Centre.

Naicker, S.M. (2000). From apartheid education to inclusive education: the challenges of transformation. Pape presented at the International Education Summit for a Democratic Society, Detroit, MI, $26-28$ June.

Navsaria, I. (2010). Written language expression in linguistically diverse classrooms in the Western Cape: a case study. Unpublished Masters dissertation. University of Cape Town.

Nida, E. (1975). Principles of correspondence In L. Venuti (Ed.), The translation studies reader (pp. 126-141). London: Routledge.

Nyika, N. (2009). Language complaints as an instrument of language rights activism: The case of PANSALB as a guardian of the right to mother-tongue education. Language Matters, 40(2), 239-260.

Obondo, M.A. (2008). Bilingual education in Africa: An overview. In J.Cummins \& N.H. Hornberger (Eds.), Encyclopaedia of language and education (2nd ed., vol. 5, pp. 151-161). New York: Springer Science.

Owens, R.E. (2002). Language development: An introduction (5th ed.). Boston: Allyn \& Bacon.

Owens, R.E. (2010). Language disorders: A functional approach to assessment and intervention (5th Ed). Boston, MA: Pearson Education.

PanSALB (2011). The Pan South African Language Board. PanSALB News, 2(5), 1-5. Retrieved on 12 Octobe 2011 from http://www.pansalb.org.za/home.html.

Paradis, J. (2004). On the relevance of specific language impairment to understanding the role of transfer in second language acquisition. Applied Psycholinguistics, 25, 67-82.

Penuel, W., Fishman, B., Yamaguchi, R., \& Gallagher, L. (2007). What makes professional development effective? Strategies that foster curriculum implementation. American Educational Research Journal, 44(4), 921-958.

Pluddemann, P., Mati, M., \& Mahlalela-Thusi, B. (2000). Problems and possibilities in multilingual classroom in the Western Cape. Final research report. Cape Town: PRAESA.

Pretorius, E. (2008). What happens to literacy in (print) poor environments? Reading in African languages and school language policies. In M. Lafon \& V. Webb (Eds.), The standardisation of African languages in
South Africa: language political realities (pp. 60-87). Johannesburg: Institut Francais d'Afrique du Sud.

Ramani, E., Kekana, T., Modiba, M., \& Joseph, M. (2007). Terminology development versus concept development through discourse: insights from a dual-medium BA degree Southern African Linguistics and Applied Language Studies 25(2), 207-221.

Ratshitanga, M. (2007, 20 March). Our present is indeed connected to our past. Pretoria News, 15.

Reagan, T. (2009). Language matters. Reflections on educational linguistics. Charlotte, NC: Information Age Publishing.

Republic of South Africa (1998, 2 November 1998). Further Education and Training Act. Government Gazette. Retrieved on 4 February 2011 from http://www.westerncape.gov.za/Text/2004/10/a98-98.pdf.

Republic of South Africa (2005). Position paper on early childhood care and development: draft for discussion Retrieved on 4 February 2011 from http://www.hsrc.ac.za/Document-1648.phtml.

Ritzman, M.J., Sanger, D., \& Coufal, K.L. (2006). A case study of a collaborative

speech-language pathologist. Communication Disorders Quarterly, 27(4), 221-231.

RCSLT (2011). Guidance on quality standards for local authorities and schools as commissioners of speech and language therapy services in the UK. Retrieved on 2 May 2011 from http://www.rcslt.org/docs/ quality_standards_scools_2011.

Ruddell, R.B., \& Ruddell, M.R. (1994). Language acquisition and literacy processes. In R.B. Ruddell, M.R Ruddell \& H. Singer (Eds.), Theoretical models and processes of reading (4th ed., pp. 83-103). Newark, DE: International Reading Association.

Scherman, V., van Staden, S., Venter, E., \& Howie, S. (2008). South African performance in PIRLS 2006: a national crisis. Symposium papers: National reflections on international comparative achievement studies (Part 4). Pretoria: University of Pretoria.

Schrage, M. (1995). No more teams! Mastering the dynamics of creative collaboration. New York: Currency Doubleday.

Scott, C. (2005). Learning to write. In H. Catts \& A. Kamhi (Eds.), Language and reading disabilities, (2nd ed. pp. 233-273). Boston, MA: Pearson.

Sen, A. (2001). Development as freedom. New York: Oxford University Press.

Singh, P. (2009). Trawling through language policy: practices and possibilities post 1994. Language Learning Journal, 37(3), 281-291.

Slabbert, J.A., de Kock, D.M., \& Hanttingh, A. (2009). The brave 'new' world of education: creating a unique professionalism. Cape Town: Juta.

Sookrajh, R., \& Joshua, J. (2009). Language matters in rural schools in South Africa: are educators making the implementation of the Language in Education Policy (1977) work? Language Learning Journal, $37(3), 323-338$.

Stackhouse, J., \& Wells, B. (1997). Children's speech and literacy difficulties I: A psycholinguistic framework London: Whurr Publishers.

Tabri, D., Chacra, K. \& Pring, T. (2010). Speech perception in noise by monolingual, bilingual and trilingual listeners. International Journal of Language and Communication Disorders, 46(4), 411-422.

Taylor, S., \& Yu, D. (2008). The importance of socio-economic status in determining educational achievement in South Africa. Development Policy Research Unit. Stellenbosch: Stellenbosch University, Department of Economics: Working Papers.

UNESCO (2005). Education for All (EFA): Global Monitoring Report. Literacy for all. Paris: UNESCO. Retrieved on 4 December 2008 from http://unesdoc.unesco.org/images/0014/001416/141639e.pdf.

UNESCO (2007). Experts' consultation on the operational definition of basic education (No. ED/BAS RVE/2009/PI/1) Paris: UNESCO.

United States Aid (2004). USAID: Sub-Saharan Africa overview. Retrieved on 30 September 2009 from http:// www.usaid.gov/policy/budget/cbj2004/sub-saharan-africa/

Ullman, M.T. (2001). The neural basis of lexicon and grammar in first and second language: The declarative procedural model. Bilingualism: Language and Cognition, 4, 105-122.

Webb, V. (2004). African languages as media of instruction in South Africa: Stating the case. Language Problems and Language Planning, 28 (2), 147-173.

Webb, V. A., Lafon, M., \& Pare, P. (2010). Bantu languages in education in South Africa - Ongekho akekho! The absentee owner. Language Learning Journal, 37(3), 273-292.

Welch, T. (2003). Educator education in South Africa before, during and after apartheid: an overview. In J. Adler \& Y. Reed (Eds.), Challenges of teacher development: an investigation of take-up in South Africa (pp. 17-35). Pretoria: Van Schaik.

Wiggins, G., \& McTighe, J. (2005) Understanding by design. Expanded 2nd edition. Upper Saddle River, NJ Prentice Hall/Pearson.

Wildsmith-Cromarty, R., \& Gordon, M. (2009). Policy versus practice: the role of the home language in learning mathematics and science in English-medium classrooms. Language Learning Journal, 37(3), 359-370.

Wilson, G., Nash, M., \& Earl, G. (2010). Supporting students with language learning difficulties in secondary schools through collaboration: The use of concept maps to investigate the impact on teachers' knowledge of vocabulary teaching. Child Language Teaching and Therapy, 26(2), 163-180

Wium, A. M., Louw, B., \& Eloff, I. (2010). Speech-language therapists supporting foundation phase educators with literacy and numeracy in a rural and township context. South African Journal of Communication Disorders, 57(1), 14-22.

Wren, Y., Roulstone, S., Parkhouse, J., \& Hall, B. (2001). A model for a mainstream school-based speech and language therapy service. Child Language Teaching and Therapy, 17(2),107-126. 